\title{
Siphonophores from surface waters of the Colombian Pacific Ocean
}

Julian Uribe-Palomino, Raúl López, Mark J. Gibbons, Felipe Gusmão and Anthony J. Richardson

\begin{abstract}
Siphonophores are colonial hydrozoans that feed on zooplankton including fish larvae, and occur throughout the world's oceans from surface waters to ocean depths. Here we describe the composition of hyponeustonic siphonophores ( $0-3 \mathrm{~m}$ depth) from the tropical Colombian Pacific Ocean based on 131 plankton samples collected between June - October from 2001 2004. Samples were dominated by species of Calycophorae, with only three species of Physonectae identified, consistent with their deeper depth distribution. Muggiaea atlantica, Chelophyes contorta, Diphyes dispar, and Eudoxoides mitra were the most common of the 21 species identified. We found moderate structuring of the siphonophore community by the salinity gradient from inshore to offshore, and greater richness during the night because of diel vertical migration. Temperature did not play a significant role in structuring siphonophore communities, perhaps because of the narrow temperature range observed ( $3.58 \mathrm{C})$. We extend the known temperature and salinity range of several species, including $\mathrm{M}$. atlantica up to temperatures of $28.68 \mathrm{C}$ and salinities down to 24.7. Interestingly, only polygastric stages of M. atlantica were found, suggesting the reproductive stage of $\mathrm{M}$. atlantica in tropical waters might be found in deeper waters. Chelophyes appendiculata was rare in our study and C. contorta was common, providing evidence they have a potential allopatric relationship, with C. contorta replacing C. appendiculata in warm water. Finally, we found siphonophore abundance was positively related to the abundance of copepods and fish eggs, with the top 13 most abundant species all having positive correlations, suggesting siphonophore abundances are tightly controlled by their food.
\end{abstract}

\section{Introduction}

Siphonophores are hydrozoans characterized by having complex colonies, comprising functional and specialized polymorphic units (zooids) that perform different tasks, including feeding and defence (gastrozooids), and reproduction (gonophores). The general body plan of siphonophores varies between taxonomic levels, and colonies range in size from a few centimetres to tens of metres (Mapstone, 2014). Some siphonophores display diel vertical migration, whilst others do not (Pugh, 1984; Mackie et al., 1988; Mapstone, 2014). They play an important role in the ecology of marine systems: they reproduce quickly (Mackie et al., 1988); they can be voracious predators of zooplankton and fish larvae (Alvariñ o, 1985; Purcell, 1985; Arai, 1988; Kr šinić \& Njire, 2001; Mills, 2001); they compete with fish for food (Arai, 1988; Buecher, 1999; Thibault-Botha et al., 2013); and they are distributed 
throughout the water column, particularly in the deep sea (Silguero \& Robison, 2000). When abundant, they can impact economic activities such as tourism and marine aquaculture (Fossa et al., 2003; Baxter et al., 2011; Licandro et al., 2012).

In the Pacific Ocean, there are many studies on the composition and distribution of siphonophores in temperate waters (Palma, 1973; 1999; Pagès et al., 1990; Gasca \& Suá rez, 1992a, b; Palma \& Rosales, 1995; Gasca, 2002; Palma \& Apablaza, 2004; Palma \& Silva, 2004; Apablaza \& Palma, 2006; Palma et al., 2007; Sanvicente-Añ orve et al., 2007, 2009; Lo et al., 2012; 2013, 2014; Gamero-Mora et al., 2015), but comparatively few from equatorial and tropical waters. Bigelow (1911) identified 40 siphonophores from samples collected during the Albatross expedition in October 1904 to March 1905, but few samples were collected from the Eastern Tropical Pacific. Alvariño (1971) also documented siphonophore species from the tropical-equatorial Eastern Pacific Ocean collected during two expeditions outside of the Colombian marine territory - Shellback (May - August 1952) and Capricorn (November 1952 - February 1953). Andrade (2012) identified 15 species around Santa Clara Island (Ecuador) from hyponeustonic samples collected in September and November 2007, with Muggiaea atlantica and Chelophyes appendiculata being the dominant species at flood tide. The only work on the composition, distribution and abundance of siphonophores from neritic equatorial waters and from the Colombian Pacific Ocean is unpublished research from the thesis of Cely \& Chiquillo (1993). They found 29 species, with Chelophyes appendiculata, Diphyes dispar and Abylopsis eschscholtzii dominant. This latter study was based on oblique samples collected in a single cruise conducted in waters adjacent to the coast in February-March 1991.

By comparison with the rest of the planktonic environment, the hyponeuston is poorly known and yet it provides an important habitat for early life history stages of fishes (Banse, 1964; Ahlstrom \& Stevens, 1976; Jeong et al., 2014), whose abundances may be impacted by siphonophores (Purcell, 1985). Here we provide new insights into the poorly known hyponeuston of the tropics, which are some of the most biodiverse areas of the world (Roy et al., 1998; Boltovskoy, 1999; Harris et al., 2000; Macpherson, 2002; PierrotBults \& Angel, 2013). We investigate siphonophore diversity within the hyponeuston for two major orders of siphonophores (Calycophorans and Physonects) and its relation to environmental variables. Samples were collected from coastal and oceanic waters of the tropical Colombian Pacific Ocean (CPO) over five cruises conducted over four consecutive years.

\section{Mate rials and methods Study region}

The study area $\left(339,000 \mathrm{~km}^{2}\right)$ was the CPO and part of the Panamá Bight (CCCP, 2002) (Figure 1). In this region, trade winds are strongest from December to March (Rodr'iguez-Rubio \& Wolfgang, 2003), so all cruises were conducted outside peak upwelling season. The development of the Colombian Current (in neritic waters) (CCCP, 2002; Mart'inez et al., 2007) and the presence of oceanic upwelling occur as a result of the presence of the NE

\section{http://repository.uwc.ac.za}


trade winds in the CPO from November-March. These oceanographic features decline once the trade winds lose intensity toward the second half of the year (Wyrtki, 1966; Rodr'iguez-Rubio \& Wolfgang, 2003) when our study was conducted.

\section{Sampling}

Five cruises were conducted on board the Colombian Army research platforms ARC-Malpelo and ARC-Gorgona on 23 June - 12 July 2001 (denoted Jun - Jul 2001), 27 August - 15 September 2001 (Aug-Sep 2001), 3-22 September 2002 (Sep 2002), 2-21 September 2003 (Sep 2003), and 16 September -8 October 2004 (Sep - Oct 2004). Biological samples and environmental data were collected between $77-848 \mathrm{~W}$ and $2-68 \mathrm{~N}$ on a fixed grid of 35 stations, although not all stations were sampled during each cruise because of severe weather conditions and technical issues (Figure 2). Stations were 30 nautical miles apart in coastal waters and 60 nautical miles apart in oceanic areas. Samples were designated as being day $(6 \mathrm{am}-6 \mathrm{pm})$ or night according to the local time of arrival at the site. Two stations (49 and 111) were sampled more than once on the cruise conducted in Jun-Jul 2001.

At each station, sea surface temperature was measured with a reversing thermometer because it could be deployed close to the sea surface. Salinity was measured with a CTD (SeaBird electronics Series SEACAT) and the first reliable data were at $4 \mathrm{~m}$ depth because of ship movement and waves. 


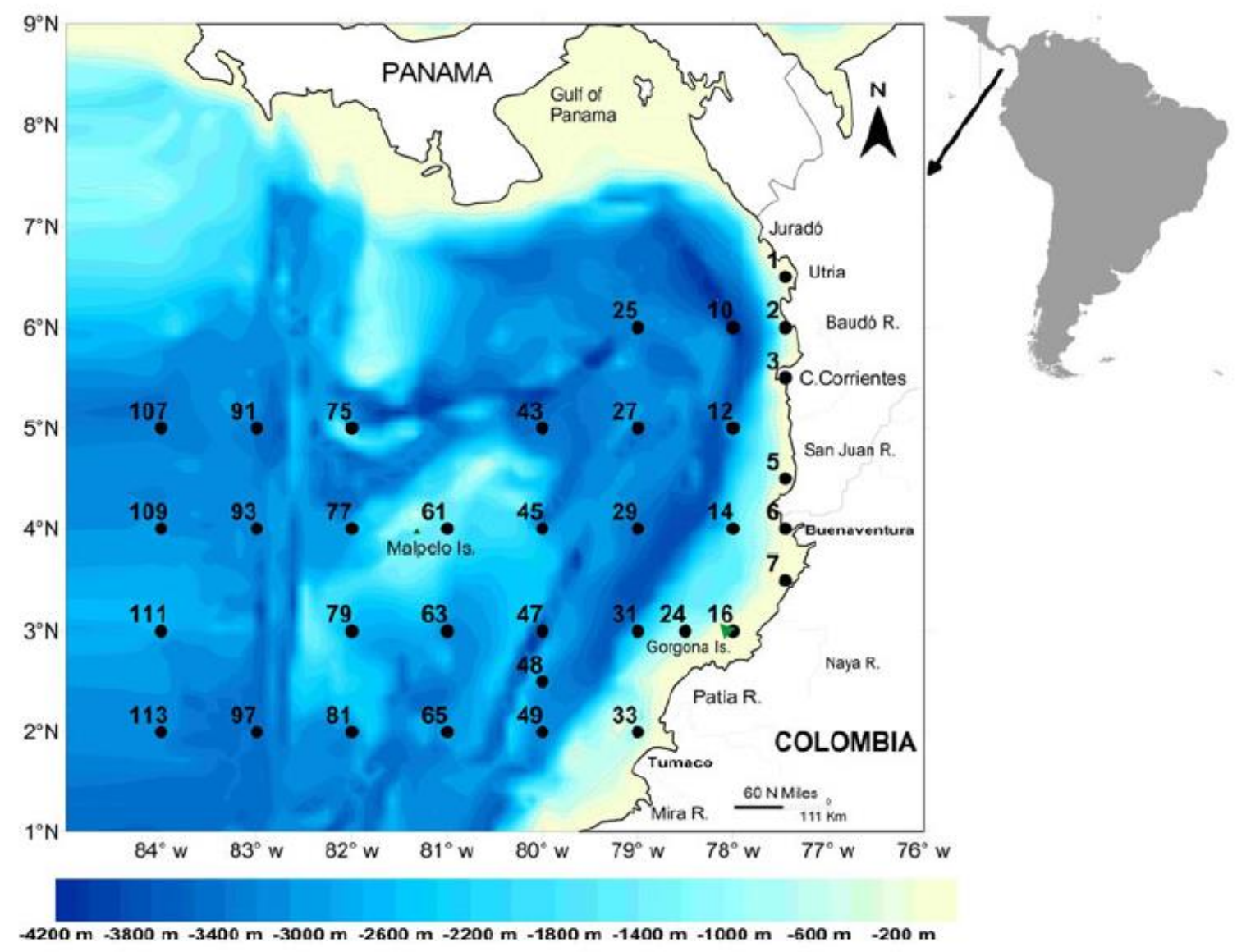

Fig. 1. Map of the Colombian Pacific Basin showing the bathymetry and location of the sampling stations. 


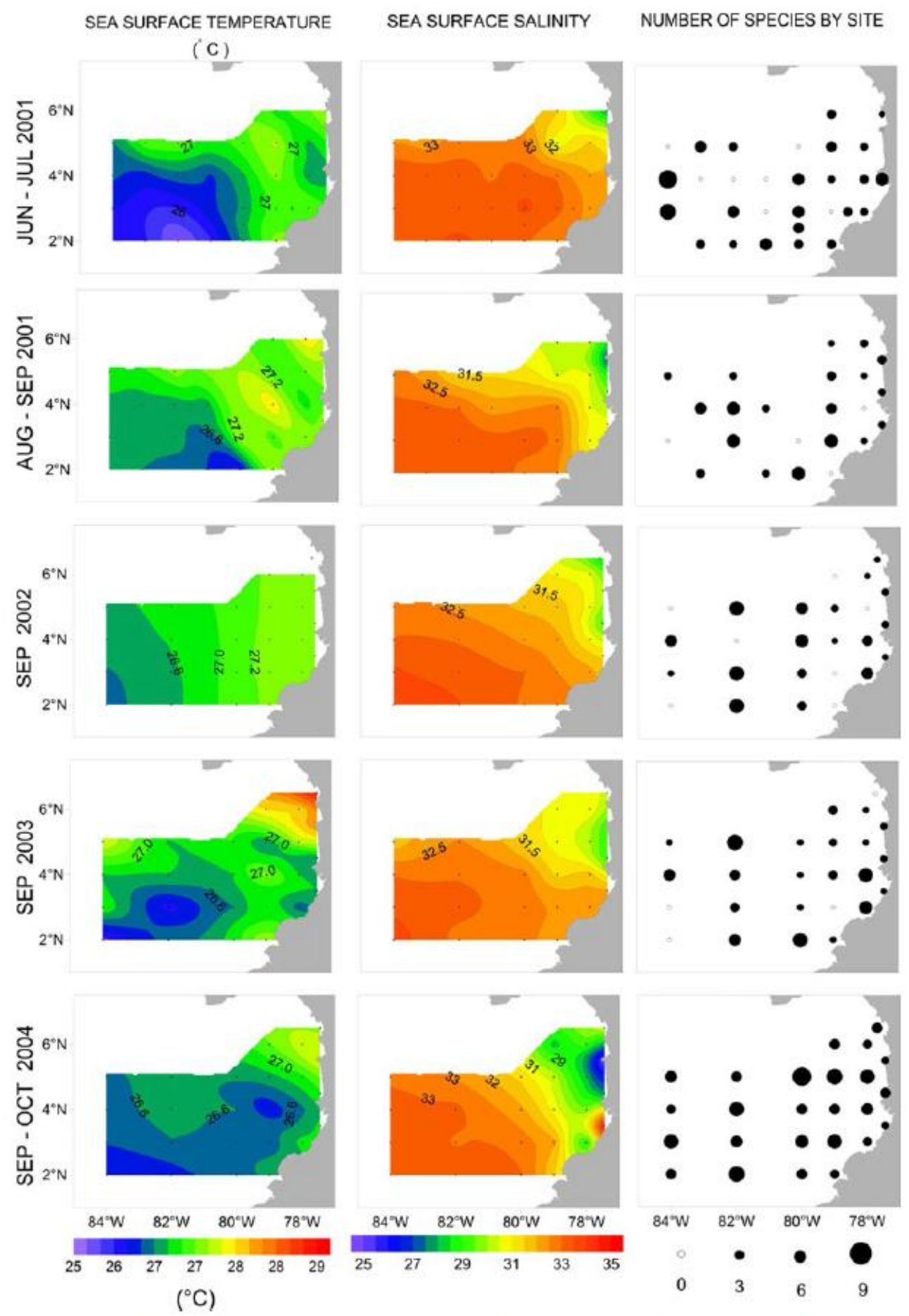

Fig. 2. Contour maps of temperature and salinity, and number of species of siphonophores found by site in the CPO during June-July 2001, August-September 2001, September 2002, September 2003 and September-October 2004.

Samples of surface water were collected at each station with a $5 \mathrm{l}$ Niskin bottle, and a $500 \mathrm{ml}$ subsample of this was stored at $2208 \mathrm{C}$ for later analysis of nutrient concentration (ammonia, nitrite, nitrate, phosphate and silicate), following protocols of Garay et al. (1993).

To investigate the siphonophore community in the hyponeuston, we collected zooplankton samples in the first $0-3 \mathrm{~m}$ of water. Plankton samples were collected using a circular net 
of $0.5 \mathrm{~m}$ diameter and $363 \mathrm{~mm}$ mesh size, following a standardized circular trawling trajectory for 10 minutes. Samples were fixed and preserved in $5 \%$ buffered formalin.

In the laboratory, all siphonophores were identified from the samples using compound (Carl Zeiss S-1000 and Leica Zoom 2000) and dissecting microscopes (Carl ZeissAxiostar). Species were identified following Pagès et al. (1992) and Palma (1973) on the basis of whole organisms (Cystonectae) or portions of colonies, nectophores, eudoxids, gonophores and bracts (Physonectae and Calycophorae). Confirmation of the species was completed in 2005 following direct communication with the late Dr Francesc Pagè s.

\section{Statistical analyses}

Most of our analyses are based on presence:absence of siphonophores as we could not estimate abundance robustly on all cruises because the flowmeter did not always work properly. For the two cruises with flowmeter data, estimates of siphonophore abundance for each species were obtained by summing the number of polygastric and reproductive stages. For Calycophorae, this was the greater of the number of anterior or posterior nectophores (or gonophores/bracts for eudoxids). For Physonectae, counts were based on pneumatophores; multiple bracts and nectophores without a pneumatophore were considered to originate from a single individual. We assessed how representative the presence:absence data were by correlating the frequency of occurrence of each species (based on presence:absence data) against abundance for cruises in Sep 2002 and Sep - Oct 2004.

To assess whether there might be bottom-up or top-down control between siphonophores and their prey, we obtained data on the abundance of copepods and fish eggs from unpublished work from the same net samples as the siphonophores. We assumed that bottom-up control would manifest as a positive relationship between siphonophore abundance (response) and copepods or fish eggs (predictors), and top-down control as a negative relationship between siphonophores and copepods or fish eggs (Richardson \& Schoeman, 2004). Visual assessment of diagnostic plots showed that $\log _{10}(x+1)$ transformation of both the response and predictors improved normality and homogeneity of variance assumptions. Data on fish egg and larval abundance were only available for the two cruises when flowmeter data were available: Sep 2002 and Sep - Oct 2004. Abundances were converted to densities (per $1000 \mathrm{~m} 3$ ), with a knowledge of the fraction of the sample examined (most commonly 1/8) and the volume of water filtered by the nets estimated using a flowmeter. Linear models were constructed in $\mathrm{R}$ and visualized using the effects package (Fox, 2003).

To map the data for each cruise, we constructed contour plots of sea surface temperature and salinity using kriging in Surferw 8.04 (Golden software, LLC, 2003). To assess the variation of environmental variables, we built a linear model with Temperature and Salinity

\section{http://repository.uwc.ac.za}


(untransformed) as response variables and included two factors, Region (Coastal (,600 $\mathrm{m}$ ) or Oceanic) and Cruise (the five surveys), and their interaction.

\section{Multivariate analyses}

To examine the response of the siphonophore community to environmental conditions, we performed non-metric Multidimensional Scaling (nMDS) analysis (Clarke et al., 2014). nMDS is an ordination technique that seeks to preserve the rank dissimilarities between objects (here samples) based on a suite of variables (here species). On the 2-D ordinations, the closer two samples are, the more similar are their communities. We used the Bray-Curtis dissimilarity measure because it is robust to joint absences, so samples do not appear closer on the ordination because they have no species in common (Clarke et al., 2014). We performed 1000 iterations using the metaMDS function in the $\mathrm{R}$ package vegan (Oksanen, 2011, 2017). We related the nMDS ordination to Region, Cruise, SST and Salinity; nutrient concentrations and chla were excluded because there were too many missing data. To aid interpretation, we included vector plots of environmental variables, species scores, and 95\% confidence limits of centroids for Regions (Coastal vs Oceanic) and Time of Day (Day vs Night) on the ordination. To assess significant differences between groups and for continuous predictors, we performed a Permutational Multivariate Analysis of Variance (ADONIS) (Anderson, 2001). This gives the significance and the proportion of variance in the multivariate data (siphonophore communities) explained individually by each of the environmental predictors, added sequentially. To identify siphonophore species that were driving community differences, we used the Dufrene - Legendre Indicator Species Analysis (Dufrene \& Legendre, 1997) in the R package labdsv. We used 0.05 as the level of significance in all statistical tests, unless otherwise specified.

\section{Results}

\section{Environmental conditions}

There were relatively small differences in temperature in the tropical CPO during the study (Figure 2). Mean SST was 26.9 8C (+0.57 8C, standard deviation) with a range of 3.5 8C, with coolest temperatures (25.5 8C) in Jun - Jul 2001 and Sep - Oct 2004 in offshore waters to the south-east of the CPO. Waters with temperature $.278 \mathrm{C}$ were located between 808W and the coast in Jun - Jul 2001, Aug - Sep 2001 and Sep 2002, and to the northeast of the CPO in Sep 2003 and Sep-Oct 2004.

The linear model for SST showed that there was no significant interaction between Region and Cruise, suggesting the temperature difference between Regions (Coastal and Oceanic) was similar among Cruises. Coastal waters were significantly warmer $(27.2+0.078 \mathrm{C}$, mean + standard error) than Oceanic $(26.7+0.068 \mathrm{C})$ waters, although the mean difference was only 0.5 8C (Figure 3A). Temperature also varied significantly among Cruises (Figure 3A): Jun - Jul $2001(26.7+0.18 C)$, Aug - Sep $2001(27.0+0.18 C)$, Sep $2002(27.1+0.18 C)$, Sep $2003(27.0+0.18 C)$ and Sep - Oct $2004(26.7+0.18 C)$, but the effect size (i.e. maximum mean difference among cruises) was only $0.48 \mathrm{C}$.

\section{http://repository.uwc.ac.za}


There was a relatively large range in salinity (10.07) among sites during the study (Figure 2). Low salinities were often found in the north-east section of the CPO and extended away from the coast. The lowest salinity (24.78) was recorded during Sep-Oct 2004 in the area off Cabo Corrientes, where a number of large rivers emerge. In general, concentrations of nutrients were often below detection levels, except for highest values near the San Juan River mouth in Sep $2002\left(\mathrm{NH}_{4} 10.29 \mathrm{mg}\right.$ at. $\mathrm{l}^{21}, \mathrm{NO}_{3} 27.8 \mathrm{mg}$ at. $\mathrm{l}^{21}, \mathrm{PO}_{4} 1.6 \mathrm{mg}$ at. $1^{21}$ and $\mathrm{SiO}_{4} 40.9 \mathrm{mg}$ at. $\mathrm{l}^{21}$; Table 1). Mean chlorophylla concentration was relatively high at times in coastal waters, up to $7.24 \mathrm{mg} \mathrm{m}^{23}$, but low offshore (Table 1 ).
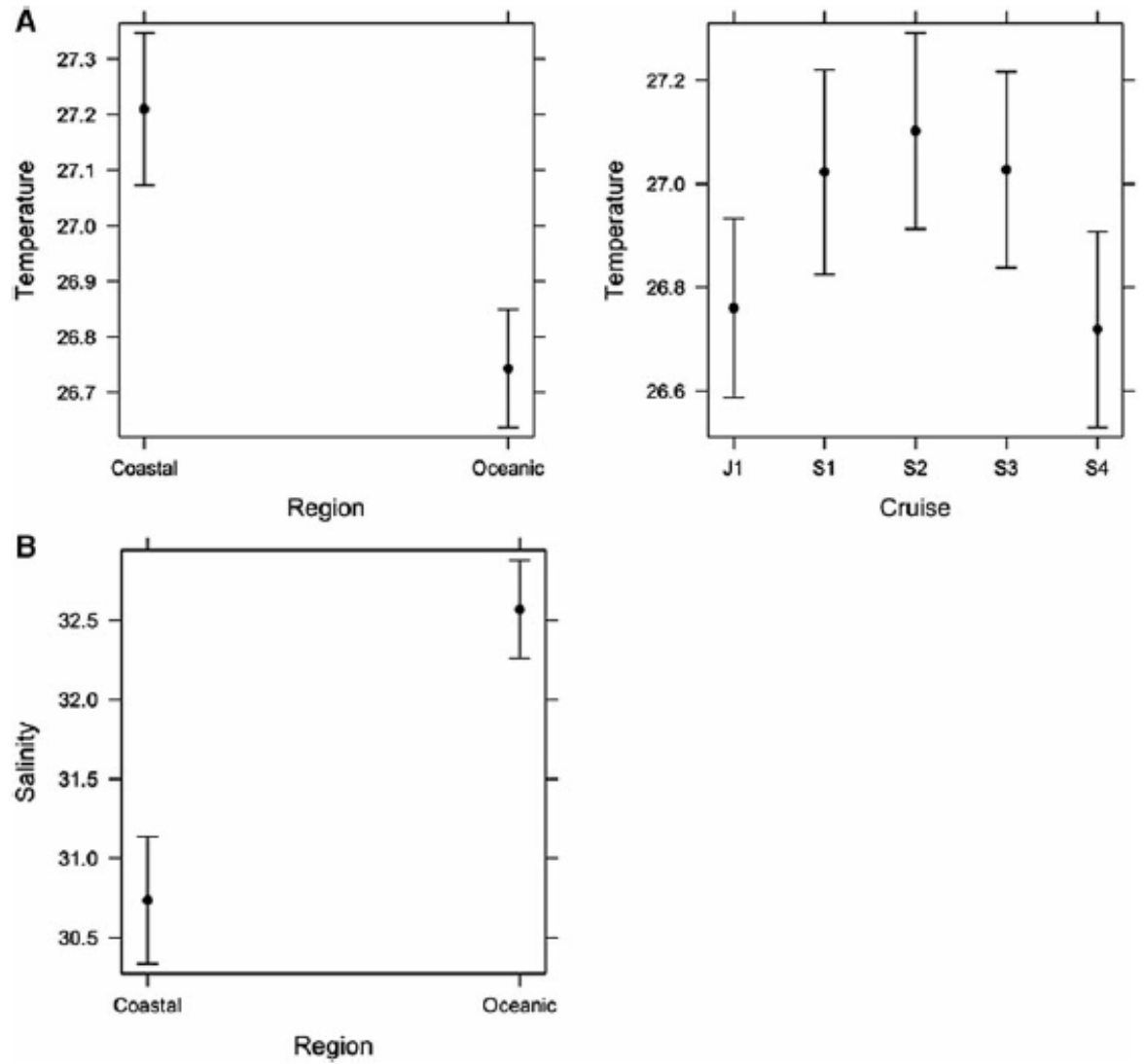

Fig. 3. Final linear models of (A) Temperature and (B) Salinity. Means \pm confidence intervals are shown.

The linear model for Salinity showed there was no significant interaction between Region and Cruise, suggesting the salinity difference between Regions (Coastal and Oceanic) was similar among Cruises. The main effect of Cruise was not significant, but Region was significant (Figure 3B). Coastal waters were significantly less saline $(30.7+0.3)$ than Oceanic waters $(32.6+0.1)$.

\section{Siphophonore species present}

A total of 21 species of siphonophores were recorded from surface waters of the CPO (Table 2). Nectophores and associated pneumatophores, and bracts were recorded for two agalmatids (Agalma okenii and Agalma elegans) and polygastric and reproductive stages for five calycophorans (Abylopsis eschscholtzii, Diphyes dispar, Diphyes bojani, Eudoxoides mitra

\section{http://repository.uwc.ac.za}


and Eudoxoides spiralis). Of these, only the eudoxid stages of D. bojani were collected in Sep 2002 and Sep 2003, and only the polygastric stages of E. spiralis were recorded in oceanic waters in Aug - Sep 2001, Sep 2002 and Sep - Oct 2004. Bassia bassensis was identified only once from a single gonophore in Jun - Jul 2001, whilst the remaining 11 species of Calycophorae were identified from polygastric stages (mainly the anterior nectophore), and Nanomia bijuga from nectophores.

The eight most common species, in decreasing order of importance (from presence:absence data), were D. dispar (67.2\%), Chelophyes contorta (51.1\%), Muggiaea atlantica (39.7\%), E. mitra (30.5\%), A. eschscholtzii (19.8\%), D. bojani (19.8\%), A. okenii (16.0\%) and A. elegans (13.0\%) and were found in all five surveys. Eudoxoides spiralis, Sulculeolaria monoica, Sulculeolaria quadrivalvis and Sulculeolaria turgida were absent in Sep 2003, and Physalia physalis was absent in Aug - Sep 2001 (Table 2). Bassia bassensis, Ceratocymba leuckartii, Chelophyes appendiculata, Hippopodus hippopus, Lensia campanella, N. bijuga, Sulculeolaria biloba and Sulculeolaria chuni were recorded sporadically.

\section{Siphonophore richness}

The species richness of siphonophores varied spatially and temporally. In oceanic waters there were up to nine species in a sample and in coastal waters up to seven species in a sample (Figure 2). There was higher richness in coastal waters off Buenaventura in Jun - Jul 2001 and Sep 2003 (Figure 2). There appeared to be higher siphonophore species richness in Sep - Oct 2004 than in other cruises. In the final linear model of siphonophore Richness (response) and Region, Time of Day and Cruise (predictors), only the main effects were significant (pseudo $\mathrm{r}^{2} 1 / 4$ 16.2\%, Figure 4A). Richness was significantly higher in Oceanic $(3.5+0.08)$ than Coastal waters $(2.2+0.12)$. Richness was also significantly higher at Night $(3.4+0.08)$ than during the Day $(2.4+0.11)$. Richness varied significantly among cruises, with significantly higher Richness in Sep - Oct 2004 (4.6 + o.13) than Jun-Jul $2001(2.8+0.13)$, Aug - Sep $2001(2.6+0.16)$, Sep $2002(2.5+$ $0.16)$ or Sep $2003(2.6+0.15)$. 


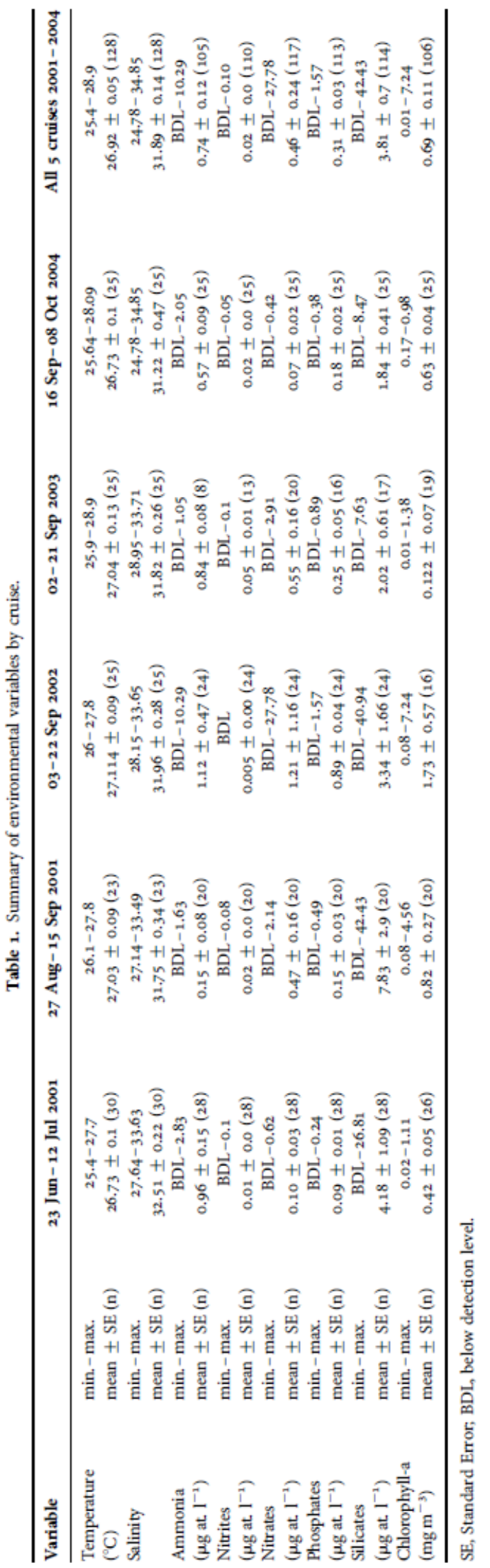

http://repository.uwc.ac.za 


\section{Siphonophore communities}

The nMDS ordination shows that there is a modest amount of structuring of the siphonophore community in the CPO (Figure 5). The Adonis model explained $10.8 \%$ of the variation in siphonophore communities, with Region (5.0\%), Time of Day (3.7\%) and Salinity (2.1\%) all significant, and Cruise and Temperature not significant. Centroids for the Coastal vs Oceanic effect are close together, but their $95 \%$ confidence intervals do not overlap, suggesting that species toward the left of the ordination tend to be more Coastal and those toward the right tend to be more Oceanic. The Indicator Species Analysis showed that the species most different between Coastal and Oceanic samples were C. contorta (IV $=0.48, \mathrm{P}=0.02$, Relative frequency of $41.0 \%$ Coastal vs $75.0 \%$ Oceanic), E. mitra (IV $=0.28$, $\mathrm{P}=0.092,25.6 \%$ Coastal vs $44.1 \%$ Oceanic), $\mathrm{D}$. bojani (IV = 0.28, $\mathrm{P}=0.01,7.7 \%$ Coastal vs $33.4 \%$ Oceanic), A. eschscholtzii (IV $=0.25, \mathrm{P}=0.01,10.3 \%$ Coastal vs $32.4 \%$ Oceanic), E. spiralis (IV $=0.15, \mathrm{P}=0.07,5.1 \%$ Coastal vs $19.1 \%$ Oceanic) and $\mathrm{S}$. monoica (IV $=0.13, \mathrm{P}=$ $0.03,0 \%$ Coastal vs $13.2 \%$ Oceanic).

The centroids for Day vs Night are separated (although still relatively close together), implying some species are different during the Day and Night. Species that were most different between Day and Night were $\mathrm{M}$. atlantica (IV $=0.36, \mathrm{P}=0.07,35.9 \%$ Day vs $57.8 \%$ Night), E. mitra (IV = 0.34, $\mathrm{P}=0.01,20.9 \%$ Day vs $48.4 \%$ Night) and S. turgida (IV = $0.11, \mathrm{P}=0.08,2.3 \%$ Day vs $12.5 \%$ Night) (see also Table 3 ), suggesting they vertically migrate.

The gradient of Salinity points toward the bottom right in the ordination, indicating B. bassensis, E. spiralis, D. bojani, contorta and A. eschscholtzii preferred more saline water, whereas H. hippopus and D. dispar preferred less saline waters. Siphonophore species were most common in waters with a salinity of $31-33.5$ (Figure 6), and this could simply reflect that there was more water of this salinity in the region (Figure 2). Interestingly, D. dispar and M. atlantica were found in water with salinity as low as 24.7 (Figure 6). Two rare species (S. chuni and H. hippopus) were also found at lower salinities (29 and 24.8, respectively). Temperature was not significant in the Adonis model. Siphonophore species were most common in waters of 26-27.5 8C (Figure 6), and this could also simply reflect that there was more water of this temperature in the region (Figure 2). Common species such as D. dispar and M. atlantica were ubiquitous throughout the study area (25.6$28.68 \mathrm{C}$ ) waters (Figure 6).

\section{Siphonophore abundances}

For the two cruises where we had abundance data, there was a significant positive correlation between species mean abundance and relative frequency $(\mathrm{r} 1 / 40.90, \mathrm{~N} 1 / 4$ 40, $\mathrm{P}$ 1/4 o.00001), providing support for the use of presence:absence data as a measure of relative abundance. Mean densities (per $1000 \mathrm{~m} 3$ ) indicate that the most abundant species were dispar (mean $=447.6+201.2$, standard error), E. mitra 201.2, standard error), E. mitra $(213.6+85.5)$, C. contorta $(189.7+46)$ and M. atlantica $(130.0+39.7)$ (Table 4). Physonectae were less numerous, and of the two species of Agalma identified, A. okenii $(53.3+29.9)$ were slightly more numerous than A. elegans $(40.1+24.3)$.

\section{http://repository.uwc.ac.za}


Densities of the reproductive stages of D. dispar were almost twice as high as those of the polygastric stages; 4.6 times in E. mitra, and almost 35 times more in D. bojani.

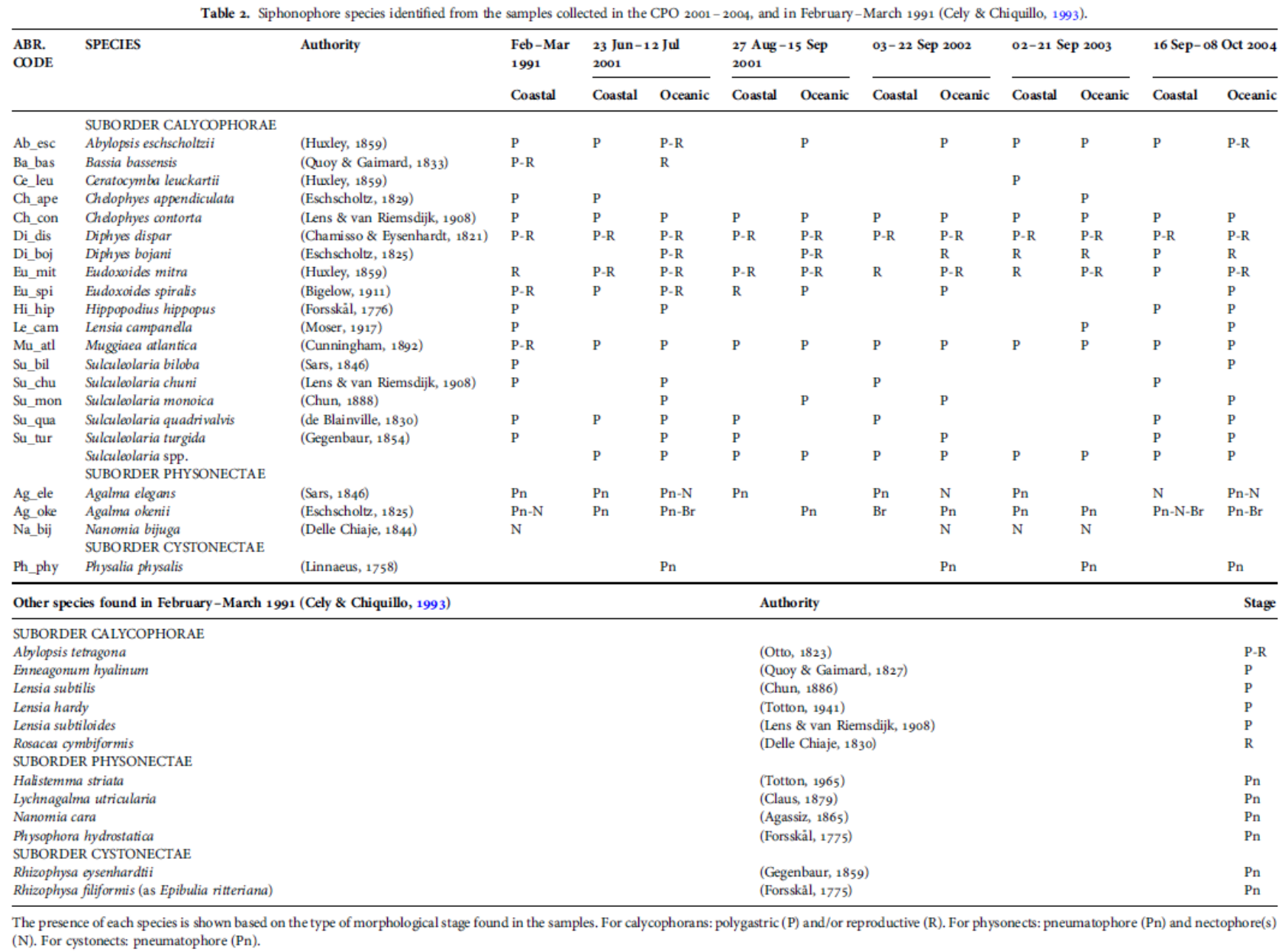



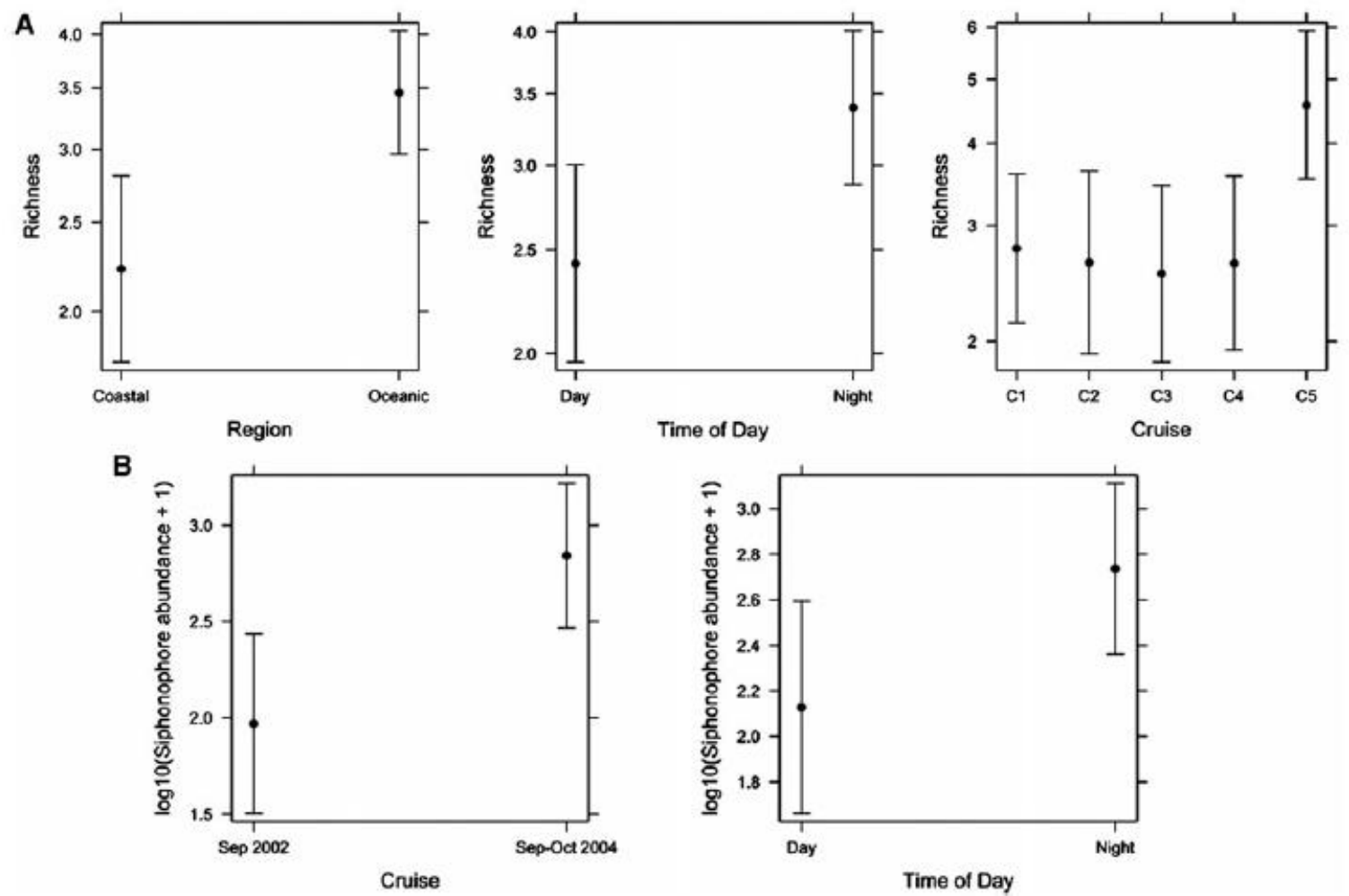

Fig. 4 Final linear modes of (A) Siphonophore richness and (B) Siphonophore abundance for Sep 2002 and Sep-Oct 2004. Means \pm confidence intervals are shown.

The linear model of Siphonophore abundance (response) showed that Cruise $(\mathrm{P}=0.0004)$ and Time of Day $(\mathrm{P}=0.05)$ were significant $\left(\mathrm{r}^{2}=33.4 \%\right)$, but Region, Temperature and Salinity were not significant (Figure 4B). Siphonophore abundance was greater in Sep-Oct 2004 than in Sep 2002, and was greater at Night than during the Day.

For the two cruises with abundance data, there was a significant positive correlation between siphonophore abundance and both total copepod abundance $(\mathrm{r}=0.64, \mathrm{~N}=40, \mathrm{P}$ $=0.00001)$ and total fish eggs $(\mathrm{r}=0.58, \mathrm{~N}=40, \mathrm{P}=0.00001)$, suggesting that there could be bottom-up control of siphonophore numbers. 


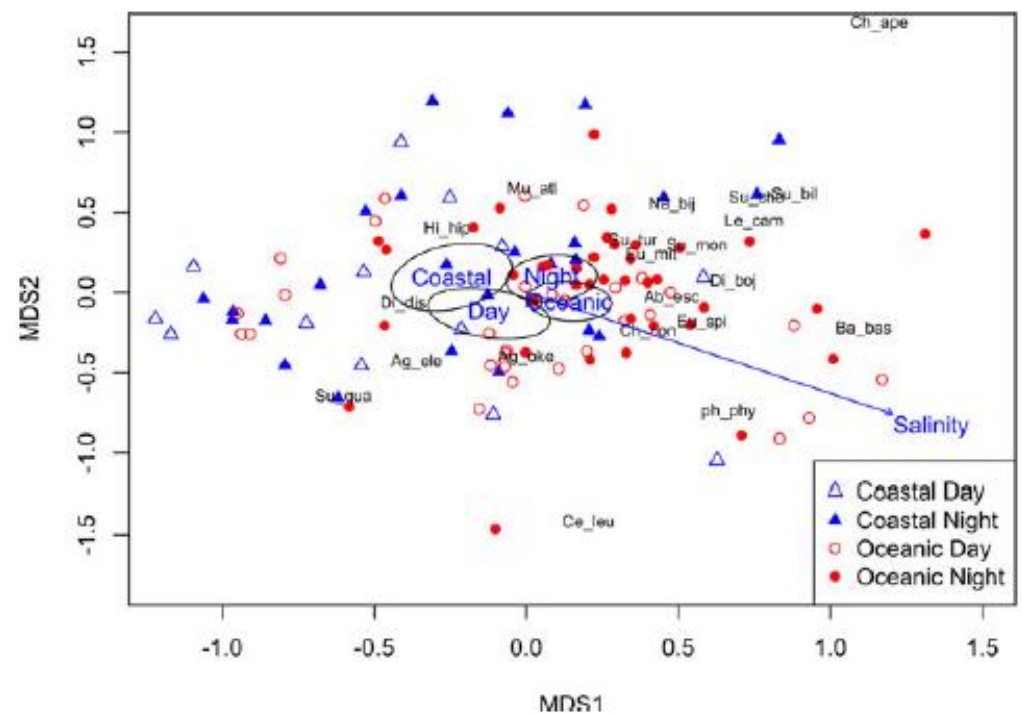

Fig. 5. A nMDS of the 21 siphonophore species, with spedies scores induded. Environmental predictors are also plotted from the final Adonis model: Region (Coastal and Oceanic) and Time of Day (Day and Night) centroids and $95 \%$ confidence intervals superimposed, and the environmental vector Salinity.

Table 3. Observation of species (\%) during the entire study, discriminated by day and night and by coastal and oceanic areas of the $\mathrm{CPO}$.

\begin{tabular}{lrllll}
\hline Siphonophore species & Overall & Day & Night & Coastal & Oceanic \\
\hline SUBORDER & & & & & \\
$\quad$ CYSTONECTAE & & & & & \\
$\begin{array}{l}\text { Physalia physalis } \\
\text { SUBORDER }\end{array}$ & 5.34 & 0.07 & 0.04 & 0.02 & 0.07 \\
$\quad$ PHYSONECTAE & & & & & \\
Agalma elegans & 12.98 & 0.13 & 0.13 & 0.15 & 0.12 \\
Agalma okenii & 16.03 & 0.13 & 0.18 & 0.17 & 0.16 \\
Nanomia bijuga & 3.05 & 0 & 0.05 & 0.02 & 0.04 \\
SUBORDER & & & & & \\
$\quad$ CALYOOPHORAE & & & & & \\
Abylopsis eschscholtzii & 19.85 & 0.16 & 0.22 & 0.08 & 0.27 \\
Bassia bassensis & 0.76 & 0 & 0.01 & 0 & 0.01 \\
Ceratocymba leuckartii & 0.76 & 0.02 & 0 & 0.02 & 0 \\
Chelophyes appendiculata & 1.53 & 0 & 0.03 & 0.02 & 0.01 \\
Chelophyes contorta & 51.15 & 0.45 & 0.55 & 0.33 & 0.61 \\
Diphyes dispar & 67.18 & 0.67 & 0.67 & 0.65 & 0.69 \\
Diphyes bojani & 19.85 & 0.16 & 0.22 & 0.06 & 0.28 \\
Eudoxoides mitra & 30.53 & 0.16 & 0.41 & 0.21 & 0.36 \\
Eudoxoides spiralis & 11.45 & 0.11 & 0.12 & 0.04 & 0.16 \\
Hippopodius hippopus & 2.29 & 0.02 & 0.03 & 0.02 & 0.02 \\
Lensia campanella & 2.29 & 0 & 0.04 & 0 & 0.04 \\
Muggiaea atlantica & 39.69 & 0.27 & 0.49 & 0.38 & 0.41 \\
Sulculeolaria biloba & 0.76 & 0 & 0.01 & 0 & 0.01 \\
Sulculeolaria chuni & 3.05 & 0.02 & 0.04 & 0.06 & 0.01 \\
Sulculeolaria monoica & 6.87 & 0.05 & 0.08 & 0 & 0.11 \\
Sulculeolaria quadrivalvis & 6.11 & 0.04 & 0.08 & 0.10 & 0.04 \\
Sulculeolaria turgida & 6.87 & 0.02 & 0.11 & 0.04 & 0.08 \\
\hline & & & & & \\
\hline & & & &
\end{tabular}

\section{Dis cussion}

Our study provides new insights into the ecology of siphonophores in the hyponeuston of the Equatorial Pacific Ocean. We show that there is a moderate structuring of the siphonophore community by environmental conditions in the CPO. This structuring is a result of the Coastal-Oceanic effect, reflected in the gradient of salinity from inshore to offshore, and also the greater siphonophore species richness during the night. The effect of 
temperature did not play a significant role in structuring siphonophore communities in the $\mathrm{CPO}$, even though there is a temperature gradient present during each cruise (warmer inshore), perhaps because of the narrow range of temperature observed during the study (3.5 8C). Our analysis suggests potential bottom-up control of the total number of siphonophores, as their density is related positively to the density of fish eggs and copepods in Sep 2002 and Sep - Oct 2004.

This is the first study to describe the surface-dwelling siphonophores from both oceanic and coastal regions of the CPO. Of the 21 species of siphonophores recorded, 17 were also recorded in the unpublished study of Cely \& Chiquillo (1993) from the coastal area of the CPO. Otherwise the species observed here from the CPO have all been recorded previously in the Pacific Ocean (Alvariñ o, 1971; Pagès et al., 1990). Species such as A. eschscholtzii, Abylopsis tetragona, B. bassensis, C. appendiculata, C. contorta, E. spiralis, M. atlantica, S. chuni and S. quadrivalvis are widely distributed in tropical waters of the Eastern Pacific (Gasca \& Suá rez, 1992a, b) and the Caribbean (Gasca, 1999), further west in the tropical Pacific (Pagès et al., 1990; Lo et al., 2012, 2014; Hsieh et al., 2013) as well as cooler Chilean (Palma, 1999; Palma \& Silva, 2004) and Peruvian (Ayón et al., 2008) waters. Most species of siphonophore have a near global distribution (Mackie et al., 1988), with all of the species found here reported from either the Atlantic (Pugh, 1999) or the Indian oceans (Daniel, 1974).

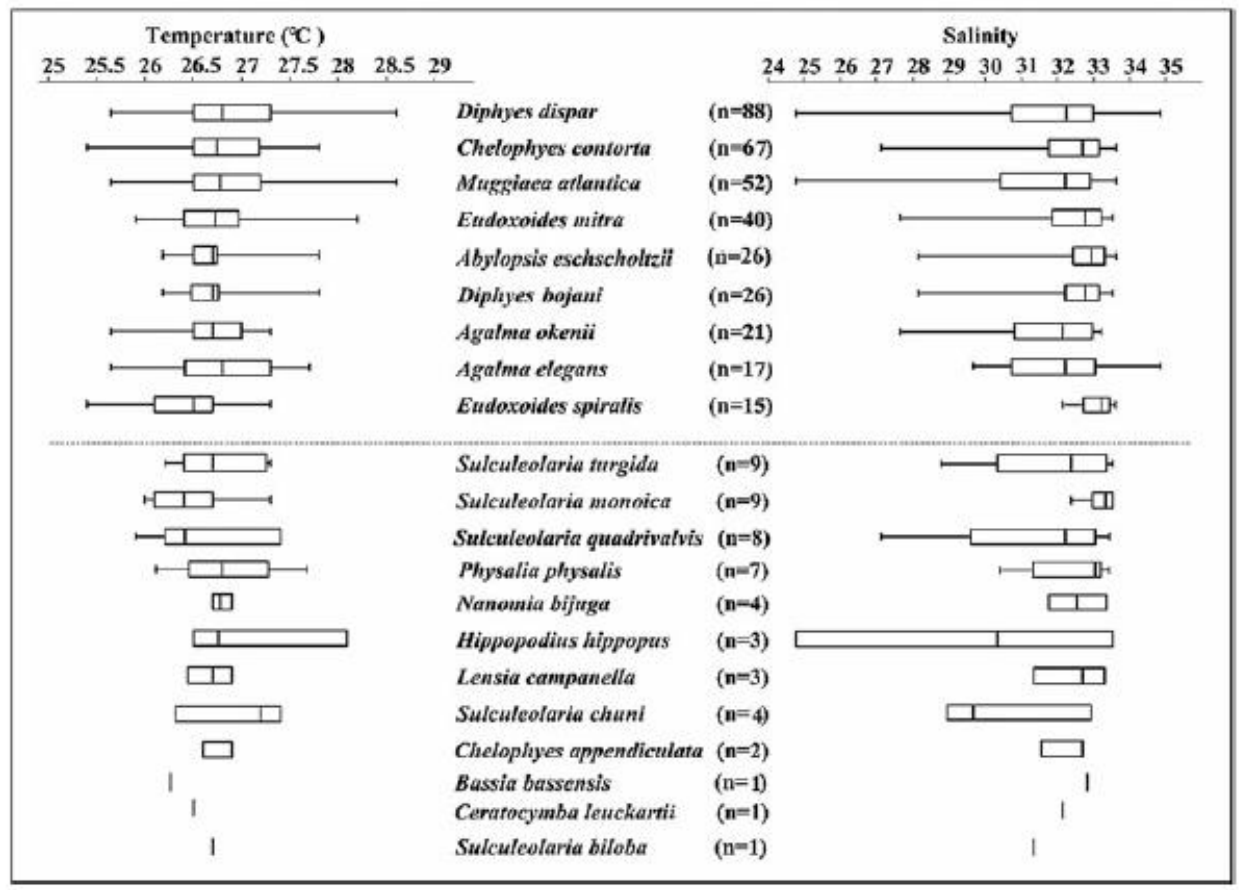

Fig. 6. Box and whisker plots of the occurrence of each siphonophore species identified during the five surveys in the Colombian Pacific Ocean in relation to

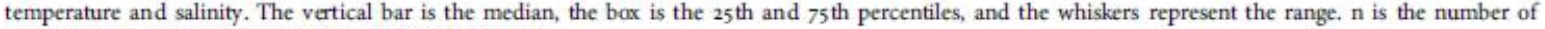
stations where each species was present during the study. 


\begin{tabular}{|c|c|c|}
\hline Siphonophore species & & $\begin{array}{l}\text { Mean abundance } \pm \text { S.E. } \\
\text { (Ind. } 1000 \mathrm{~m}^{-3} \text { ) } \mathrm{N}=40\end{array}$ \\
\hline \multicolumn{3}{|l|}{ SUBORDER } \\
\hline $\begin{array}{l}\text { Physalia physalis } \\
\text { SUBORDER } \\
\text { PHYSONECTAE }\end{array}$ & & $3.38 \pm 2.41$ \\
\hline $\begin{array}{l}\text { Agalma okenii } \\
\text { Agalma elegans }\end{array}$ & & $\begin{array}{l}53.28 \pm 29.93 \\
40.08 \pm 24.34\end{array}$ \\
\hline $\begin{array}{l}\text { SUBORDER } \\
\text { CALYOOPHORAE }\end{array}$ & & \\
\hline $\begin{array}{l}\text { Abylopsis eschscholtzii } \\
\text { Chelophyes contorta }\end{array}$ & & $\begin{array}{r}30.82 \pm 10.07 \\
189.75 \pm 45.91\end{array}$ \\
\hline Diphyes dispar & $\begin{array}{l}\text { Polygastric } \\
\text { Reproductive } \\
\text { Total }\end{array}$ & $\begin{array}{l}155.28 \pm 30.33 \\
292.34 \pm 189.83 \\
447.62 \pm 201.24\end{array}$ \\
\hline Diphyes bojani & $\begin{array}{l}\text { Polygastric } \\
\text { Reproductive } \\
\text { Total }\end{array}$ & $\begin{array}{c}1.10 \pm 0.85 \\
38.43 \pm 15.28 \\
39.53 \pm 15.23\end{array}$ \\
\hline Eudoxoides mitra & $\begin{array}{l}\text { Polygastric } \\
\text { Reproductive } \\
\text { Total }\end{array}$ & $\begin{array}{r}38.03 \pm 18.72 \\
175.59 \pm 74.04 \\
213.63 \pm 85.52\end{array}$ \\
\hline Eudoxoides spiralis & & $12.65 \pm 9.48$ \\
\hline Hippopodius hippopus & & $4.68 \pm 3.38$ \\
\hline Lensia campanella & & $9.59 \pm 8.20$ \\
\hline Muggiaea atlantica & & $130.04 \pm 39.69$ \\
\hline Sulculeolaria biloba & & $1.48 \pm 1.48$ \\
\hline Sulculeolaria dhuni & & $4.31 \pm 3.01$ \\
\hline Sulculeolaria monoica & & $4.74 \pm 3.54$ \\
\hline Sulculeolaria quadrivalvis & & $5.84 \pm 3.57$ \\
\hline Sulculeolaria turgida & & $32.76 \pm 23.19$ \\
\hline Variables & Units & mean \pm S.E. $N=40$ \\
\hline Salinity & & $31.30 \pm 0.32$ \\
\hline Temperature & ${ }^{\circ} \mathrm{C}$ & $26.93 \pm 0.08$ \\
\hline Phosphates & $\mu \mathrm{g}$.at. $\mathrm{I}^{-1}$ & $0.45 \pm 0.06$ \\
\hline Silicates & $\mu \mathrm{g}$-at. $\mathrm{I}^{-1}$ & $1.90 \pm 0.30$ \\
\hline Chlorophyll- $a$ & $\mathrm{mg} \cdot \mathrm{m}^{-3}$ & $0.76 \pm 0.15$ \\
\hline Abundance of copepods & ind. $1000 \mathrm{~m}^{-3}$ & $572,990.53 \pm 324,417.15$ \\
\hline Abundance of fish eggs & ind. $1000 \mathrm{~m}^{-3}$ & $63,120.12 \pm 25,684.12$ \\
\hline $\begin{array}{l}\text { Total abundance of } \\
\text { siphonophores }\end{array}$ & ind. $1000 \mathrm{~m}^{-3}$ & $1224.17 \pm 274.16$ \\
\hline Filtered volume by net & $\mathrm{m}^{3}$ & $119.01 \pm 4.63$ \\
\hline
\end{tabular}

All species found in our study are epipelagic (Mackie et al., 1988; Mapstone, 2014) and perform vertical migration (Pugh, 1984; Mackie et al., 1988), which explains the higher richness we found at night. Consistent with the idea that there is a peak in siphonophore richness in subtropical/tropical waters (Mackie et al., 1988; Boltovskoy, 1999; Macpherson, 2002; Pierrot-Bults \& Angel, 2013), we found more species (21 species) than in temperate waters such as off Chile (16 species, Palma, 1999) and in the Mediterranean Sea (12 species, Thibault-Botha et al., 2013).

Our study provides several other interesting findings that we will describe in more detail.

\section{Calycophorans dominate the hyponeuston}

Our samples were dominated by species of Calycophorae, both in terms of abundance (the seven most abundant species were all calycophorans) and richness, with six times as many species present as Physonectae. Only two species of physonects were commonly

$$
\text { http://repository.uwc.ac.za }
$$


encountered (Agalma okenii and A. elegans), with a third (Nanomia bijuga) present in only four samples. Although calycophorans are usually more common than the more fragile physonects in plankton samples (Pugh, 1974; Gasca \& Suárez, 1992a, b; Mapstone, 2014), this effect could have been exaggerated because many physonect species are generally found deeper in the water column than calycophorans (Robison et al., 1998; Silguero \& Robison, 2000). Similarly, no physonectids were found in other eastern Pacific surface waters surrounding Easter Island (Palma, 1999) and Santa Clara Island in Ecuador (Andrade, 2012). Studies on siphonophores from other tropical, subtropical and temperate regions all indicate a predominance of calycophorans in the hyponeuston (Pagès et al., 1990; Andrade, 2012; Thibault-Botha et al., 2013; Jeong et al., 2014).

\section{Why are there fewer than expected siphonophore species in our study?}

The number of species found in our study (21 species) is lower than other tropical studies in the eastern Pacific by Cely \& Chiquillo (1993) or Gasca \& Suá rez (1992a) (29 species in both studies), both of which collected fewer samples than our study. Here are two potential explanations.

First, both Cely \& Chiquillo (1993) and Gasca \& Suá rez (1992a) sampled throughout the water column and it is generally accepted that the number of siphonophore species in the hyponeuston is less than the number in the rest of the water column (Hempel \& Weikert, 1972; Pagès et al., 1990; Andrade, 2012). This is partly because physonects are relatively rare in the hyponeuston (Robison et al., 1998; Silguero \& Robison, 2000); we only recorded three species, although other factors might be at play.

The second potential explanation is that the Cely \& Chiquillo (1993) and Gasca \& Suá rez (1992a) studies both included upwelling conditions, whereas there was no upwelling during our study. There is generally greater richness of siphonophore species in upwelled water, such as off the Peruvian coast (Ayó n et al., 2008), the Californian coast (Gasca \& Suá rez, 1992b), the Dome of Costa Rica (Gasca \& Suárez, 1992a), the Benguela off South Africa (Thiriot, 1978; Gibbons \& Thibault-Botha, 2002; Thibault-Botha \& Gibbons, 2005). During the study by Cely \& Chiquillo (1993) in the CPO, the combination of north-east trade winds (Rodr'iguez-Rubio \& Wolfgang, 2003) and the development of the Colombian current (CCCP, 2002) led to active up-welling. Further, we found only one species of Lensia (L. campanella was found only three times), whereas Cely \& Chiquillo (1993) found three Lensia species (L. subtilis, L. hardy, L. subtiloides) during the upwelling season (DecMar) in the CPO. Other studies in colder waters, such as Thibault-Botha et al. (2013) from the Bay of Marseilles, have found more (four) Lensia species. Lensia are often considered to be restricted to cooler waters (Mackie et al., 1988; Mapstone, 2014). In tropical waters, Lensia might be more abundant in colder waters below the thermocline, and only reach the surface during active upwelling. 


\section{Potential allopatric relationship between Chelophyes appendiculata and Chelophyes contorta}

It was surprising that $\mathrm{C}$. appendiculata was rare in our study and that C. contorta was much more common, opposite to the findings of Andrade (2012) and of Cely \& Chiquillo (1993). This difference can be explained by the suggested allopatric relationship in the distribution of $\mathrm{C}$. appendiculata and contorta, with $\mathrm{C}$. appendiculata replaced by C. contorta in warmer water (Alvariñ o, 1971). Mean sea temperatures were considerably cooler in the study by Andrade (2012) (22.8 8C) than the present study (26.9 8C), favouring C. appendiculata over C. contorta. Similarly, sea temperatures were also likely to be cooler in the study by Cely \& Chiquillo (1993) because the CPO in Feb - Mar is influenced by trade winds (Wyrtki, 1966) that stimulate oceanic upwelling (Rodr'iguez-Rubio \& Wolfgang, 2003) and lead to cooler waters, again favouring C. appendiculata over C. contorta.

\section{Warmer upper thermal limit for Muggiaea atlantica}

Although M. atlantica is a widely distributed species in warm and cold temperate waters (Alvarin o, 1971; Mapstone, 2014) and is probably the best-studied siphonophore (ThibaultBotha et al., 2004; Batistić et al., 2013; Blackett et al., 2014, 2015), our data indicate that M. atlantica can be found in temperatures up to $28.68 \mathrm{C}$, far beyond the upper critical limit (24 8C) proposed by Batistić et al. (2013). This could suggest some form of local population adaptation, perhaps with regard to eudoxid production.

Whilst M. atlantica has a wide distribution in tropical shelf waters of Colombia (Cely \& Chiquillo, 1993) and Panamá (Alvariñ o, 1971, 1974), it is also common in the Humboldt Current (Bigelow, 1911; Santander et al., 1981) and in neritic and oceanic waters off Chile (Palma \& Silva, 2004; Pavez et al., 2010). Indeed, Palma \& Silva (2004) extend the distribution of this species to sub-Antarctic latitudes of Chile, where they found it at a range of temperatures from 4-13 8C. Temperatures .10 8C seem to stimulate eudoxid production for this species, as has been found by Blackett et al. (2014) in an extensive study in the Western English Channel. However, in warmer waters M. atlantica typically is replaced by Muggiaea kochii (Will, 1844) (Russell, 1934; Alvariño, 1971; Carré \& Carré, 1991), but this species was not observed in our study even though Alvariñ o (1974) recorded M. kochii in the Pacific waters of Panamá.

\section{Lower salinity tolerances for some species}

Siphonophores are an exclusively marine group and it is presumed that they have an aversion to low salinity water. Sanvicente-Añ orve et al. (2007) investigated siphonophores in coastal waters of the Caribbean and extended the salinity tolerance of D. bojani, E. mitra, D. dispar and M. atlantica down to 30.7, but there was no water below this salinity in their study. Blackett et al. (2015) further extended the salinity tolerance of M. atlantica down to 28.5. We found C. contorta, bojani and E. mitra down to a salinity of "'"27.5, and D. dispar and M. atlantica down to 24.7. These species thus have a lower salinity tolerance than previously recorded.

\section{http://repository.uwc.ac.za}




\section{Reproductive and polygastric stages of calycophorans}

We found that three dominant species of siphonophore (D. dispar, D. bojani and E. mitra) had more reproductive than polygastric stages, which suggests their populations are growing rapidly. For example, the number of reproductive stages of D. dispar were almost twice the number of polygastric stages in Sep 2002 and Sep - Oct 2004. Favourable environmental conditions for siphonophores stimulate the production of a high number of reproductive stages (Gasca, 1999). Interestingly, only polygastric stages of M. atlantica were found. The possibility that the reproductive stage of M. atlantica in tropical waters might be found in deeper waters where the temperature is more appropriate for its production warrants further study.

\section{Siphonophore abundance is related to their prey abundance}

We found siphonophore abundance was positively related to the abundance of copepods and fish eggs during Sep 2002 and Sep - Oct 2004. The top 13 most abundant species (D. dispar, E. mitra, C. contorta, M. atlantica, A. okenii, A. elegans, D. bojani, S. turgida, A. eschscholtzii, E. spiralis, L. campanella, S. quadrivalvis and S. monoica) all have positive correlations with both copepod abundance and fish eggs. These positive correlations imply bottom-up control of siphonophores by their common prey (Richardson \& Schoeman, 2004). There is growing evidence that the abundance of siphonophores is related to their prey. In Mexican Caribbean waters, Sanvicente-Añ orve et al. (2007) found a significant relationship between the community of siphonophores and the zooplankton wet biomass. In waters of the Mediterranean Sea, Ferná ndez de Puelles et al. (2007) found a positive correlation between the abundance of Muggiaea, Lensia, Eudoxoides and Abylopsis, and abundance of copepods. In subtropical waters of Taiwan, Lo et al. (2014) suggested that the abundance and distribution of siphonophores are related to zooplankton biomass.

\section{Conclusion}

This study provides new insights into the poorly known hyponeuston of the tropics. The moderate structuring of the siphonophore community found in our study is likely to be related to the gradient of salinity from inshore to offshore in waters from the CPO in the non-upwelling season. However, further research is required to determine the effect of environmental variables on the diversity, distribution and abundance of siphonophore species from the Equatorial Tropical Pacific during upwelling. A more comprehensive study of this group of cnidarians during upwelling season also might help to clarify the finding from our study related to the trophic relation between the siphonophores community and their most common prey (copepods, fish eggs) in the hyponeuston and in the water column from coastal and oceanic regions of the CPO.

\section{Suppl emen ta ry materi al}

The supplementary material for this article can be found at https://doi.org/10.1017/So025315417002065.

\section{http://repository.uwc.ac.za}




\section{Acknowledgements}

We thank the Vicerrector'ia de investigaciones of the Universidad Nueva Granada and the Centro Control Contaminación del Pacífico CCCP-DIMAR, for supporting the research on zooplankton from the Colombian Pacific Ocean. We also want to thank the crew of the Colombian Research Platforms (ARC-Malpelo and ARC-Providencia) for their invaluable help in collecting samples and environmental information in the field. Thanks to Eddie Farid (Gorgona drifter), Gloria Giraldo from the Library of the Universidad de Bogotá Jorge Tadeo Lozano for bibliographic support, Andrea Uribe-Palomino for her collaboration gathering data in Colombia and Frank Coman for helping to review the drafts of the manuscript. The authors would like to dedicate this article to the memory of Dr Francesc Pagès and his work on siphonophores around the globe. The authors thank the three anonymous reviewers for their time and constructive comments that contributed to improvement of the manuscript.

\section{Fin a n ci a 1 s upport}

This study is part of the project CIAS 2004-016, entitled: 'Variación espacio temporal del zooplancton durante los cruceros de julio y septiembre de 2005 de la serie ERFEN en el océano Pac'ífico colombiano'. This project was financially supported by the Vicerrectoría de Investigaciones from the Universidad Militar Nueva Granada - Colombia. 


\section{References}

Ahlstrom E.H. and Stevens E. (1976) Report of neuston (surface) collections made on an extended CalCOFI cruise during May 1972. California Cooperative Oceanic Fish. Investigations Report 18, 167-180.

Alvariñ o A. (1971) Siphonophores of the Pacific with a review of the world distribution. Bulletin of the Scripps Institution of Oceanography University of California 16, 432.

Alvariñ o A. (1974) Distribution of siphonophores in the regions adjacent to the Suez and Panama Canals. Fishery Bulletin 72, 527-546.

Alvariñ o A. (1985) Predation in the plankton realm; mainly with reference to fish larvae. Investigaciones Marinas CICIMAR 2, 1-122.

Anderson M.J. (2001) A new method for non-parametric multivariate analysis of variance. Austral Ecology 26, 32-46.

Andrade C. (2012) Sifonó foros (Cnidaria, Hydrozoa) de aguas superficiales alrededor de la Isla Santa Clara, durante Septiembre y Noviembre del 2007. Acta Oceanográ fica del Paćíico 17, 139-146.

Apablaza P. and Palma S. (2006) Efecto de la zona de m'inimo ox'ígeno sobre la migración vertical de zooplancton gelatinoso en la bah'ía de Mejillones. Investigaciones Marinas $34,81-95$.

Arai M.N. (1988) Interactions of fish and pelagic coelenterates. Canadian Journal of Zoology 66, $1913-1927$.

Ayó n P., Criales-Hernandez M.I., Schwamborn R. and Hirche H.J. (2008) Zooplankton research off Peru: a review. Progress in Oceanography 79, 238-255.

Banse K. (1964) On the vertical distribution of zooplankton in the sea. Progress in Oceanography 2, 53-125.

Batistić M., Lučić D., Carić M., Garić R., Licandro P. and Jasprica N. (2013) Did the alien calycophoran Muggiaea atlantica outcompete its native congeneric M. kochii in the marine lakes of Mljet Island (Croatia)? Marine Ecology 34(Suppl. 1), 3-13.

Baxter E.J., Rodger H.D., McAllen R. and Doyle T.K. (2011) Gill disorders in marine-farmed salmon: investigating the role of hydrozoan jellyfish. Aquaculture Environment Interactions 1, 245-257.

Bigelow H.B. (1911) The Siphonophorae. Memoirs of the Museum of Comparative Zoology at Harvard College 38, 173-401.

Blackett M., Licandro P., Coombs S.H. and Lucas C.H. (2014) Long-term variability of the siphonophores Muggiaea atlantica and M. kochii in the Western English Channel. Progress in Oceanography 128, 1-14.

Blackett M., Lucas C., Harmer R. and Licandro P. (2015) Population ecology of Muggiaea atlantica (Cnidaria, Siphonophora) in the Western English Channel. Marine Ecology Progress Series 535, 129-144.

Boltovskoy D. (1999) South Atlantic zooplankton, vol. 1. Leiden: Backhuys.

Buecher E. (1999) Appearance of Chelophyes appendiculata and Abylopsis tetragona (Cnidaria, Siphonophora) in the Bay of Villefranche, north-western Mediterranean. Journal of Sea Research 41, 295-307. 
Carré C. and Carré D. (1991) A complete life cycle of the calycophoran siphonophore Muggiaea kochii (Will) in the laboratory, under different temperature conditions: ecological implictions. Philosophical Transactions of the Royal Society B: Biological Sciences 334, 27-32.

CCCP (2002) Compilación Oceanográ fica de la Cuenca Paćlfica colombiana. Dirección General Mar'itima, Tumaco, Colombia.

Cely H.A. and Chiquillo J.E. (1993) Quetognatos, sifonó foros e hidromedusas de la región costera del Pacífico colombiano. Thesis. Universidad de Bogotá Jorge Tadeo Lozano, Bogotá, Colombia.

Clarke K.R., Gorley R.N., Somerfield P.J. and Warwick R.M. (2014) Change in marine communities: an approach to statistical analysis and interpretation, 3rd edition. Plymouth: PRIMER-E, 260 pp.

Daniel R. (1974) Siphonophora from the Indian Ocean, Vol. 15, No. 4. Zoological Survey of India.

Dufrene M. and Legendre P. (1997) Species assemblages and indicator species: the need for a flexible asymmetrical approach. Ecological Monographs 67,345-366.

Ferná ndez de Puelles M.L., Alemany F. and Jansá J. (2007) Zooplankton time-series in the Balearic Sea (Western Mediterranean): variability during the decade $1994-2003$. Progress in Oceanography 74, 329-354.

Fossa J.H., Flood P.R., Olsen A.B. and Jensen F. (2003) Små og usynlige, men plagsomme maneter av arten Muggiaea atlantica (Small and invisible, but troublesome jellyfish of the species Muggiaea atlantica). Fisken Og Havet (Fish and Sea) 2, 99-103.

Fox J. (2003) Effect displays in R for generalised linear models. Journal of Statistical Software 8, $1-27$.

Gamero-Mora E., Ceballos-Corona G., Gasca R. and Morales-Blake A. (2015) Analisis de la comunidad del zooplancton gelatinoso (Hydrozoa, Ctenophora, Thaliacea) en el Pacifico central mexicano, abril-mayo 2011. Revista de Biologia Marina y Oceanografia 50, 111-124.

Garay J., Panizzo L., Ram'irez G. and Sá nchez J. (1993) Manual de té c-nicas analíticas de pará metros f'isico-qu'imicos y contaminantes marinos. Cartagena: Oceanográ ficas, Centro de Investigaciones Hidrográ ficas, $\mathrm{CIOH}$.

Gasca R. (1999) Siphonophores (Cnidaria) and summer mesoscale features in the Gulf of Mexico. Bulletin of Marine Science 65, 75-89.

Gasca R. (2002) Lista faun istica y bibliograf'ia comentadas de los sifonó - foros (Cnidaria?: Hydrozoa) de México. Anales del Insittuto de Biolog'́a, Universidad Nacional Autó noma de M'exico 73, 123-143.

Gasca R. and Suá rez E. (1992a) Sifonó foros (Cnidaria:Siphonophora) del Domo de Costa Rica. Revista de Biolog'́a Tropical 40, 125-130.

Gasca R. and Suá rez E. (1992b) Sifonoforos (Cnidaria: Hydrozoa) de la zona sudoccidental de la Peninsula de Baja California, en invierno y verano durante El Nino 1983. Revista de Investigación Cientifica 3, 37-46. 
Gibbons M.J. and Thibault-Botha D. (2002) The match between ocean circulation and zoogeography of epipelagic siphonophores around southern Africa. Journal of the Marine Biological Association of the United Kingdom 82, 801-810.

Golden software, LLC (2003) Surfer (version 8.04). Windows platform. Golden, Colorado. www.goldensoftware.com

Harris R., Wiebe P., Lenz J., Skjoldal H.R. and Huntley M. (2000) ICES zooplankton methodology manual. London: Academic Press.

Hempel G. and Weikert H. (1972) The neuston of the sub-tropical and boreal North-east Atlantic: a review. Marine Biology 13, 70-88.

Hsieh H.Y., Yu S.F. and Lo W.T. (2013) Influence of monsoon-driven hydrographic features on siphonophore assemblages in the Taiwan Strait, Western North Pacific Ocean. Marine and Freshwater Research 64, 348-358.

Jeong H.G., Suh H.L., Lee W. and Soh H.Y. (2014) Seasonal variation of the neustonic zooplankton community in southern waters of Korea. Ocean Science Journal 49, 167181.

Kr sinić F. and Njire J. (2001) An invasion by Muggiaea atlantica Cunningham 1892 in the northern Adriatic Sea in the summer of 1997 and the fate of small copepods. Acta Adriatica 42, 49-59.

Licandro P., Souissi S., Ibanez F. and Carré C. (2012) Long-term variability and environmental preferences of calycophoran siphonophores in the Bay of Villefranche (north-western Mediterranean). Progress in Oceanography 97-100, 152-163.

Lo W.T., Kang P.R. and Hsieh H.Y. (2012) Siphonophores from a transect off southern Taiwan between the Kuroshio current and South China sea. Zoological Studies 51, 1354-1366.

Lo W.T., Yu S.F. and Hsieh H.Y. (2013) Effects of summer mesoscale hydrographic features on epipelagic siphonophore assemblages in the surrounding waters of Taiwan, Western North Pacific Ocean. Journal of Oceanography 69, 495-509.

Lo W.T., Yu S.F. and Hsieh H.Y. (2014) Hydrographic processes driven by seasonal monsoon system affect siphonophore assemblages in tropical-subtropical waters (Western North Pacific Ocean). PLoS ONE 9, 1-19.

Mackie G.O., Pugh P.R. and Purcell J.E. (1988) Siphonophore biology. Advances in Marine Biology 24, 97-262.

Macpherson E. (2002) Large-scale species-richness gradients in the Atlantic Ocean. Proceedings of the Royal Society of London B: Biological Sciences 269, 1715-1720.

Mapstone G.M. (2014) Global diversity and review of Siphonophorae (Cnidaria: Hydrozoa). PLOS ONE 9, 1-37.

Mart'inez-Aguilar T.I., Giraldo Ló pez A. and Rodrínguez-Rubio E. (2007) Zooplancton en la Corriente de Colombia, Paćífico Colombiano, durante Marzo de 2006. Boletin Cient'́fico CCCP 14, 69-82.

Mills C.E. (2001) Jellyfish blooms: are populations increasing globally in response to changing ocean conditions? Hydrobiologia 451, 55-68.

Oksanen J. (2011) Multivariate analysis of ecological communities in R: vegan tutorial. R package version $3 \cdot 3 \cdot 3$. 
Oksanen J. (2017). Package 'vegan'. https://cran.r-project.org. 292pp.

Page`s F., Gili J.M. and Bouillon J. (1990) The siphonophores (Cnidaria, Hydrozoa) of Hansa Bay, Papua New Guinea. Indo-Malayan Zoology 6, 133-140.

Pagès F., Gili J.M. and Bouillon J. (1992) Siphonophores (Cnidaria, Hydrozoa) of the Benguela Current (Southeastern Atlantic). Scientia Marina 56, 65-112.

Palma S. (1973) Contribución al estudio de los sifonó foros encontrados frente a la costa de Valpara' 1so. I. taxonom'ía. Investigaciones Marinas 4, 17-88.

Palma S. (1999) Sifonó foros (Cnidaria, Hydrozoa) de aguas superficiales de Isla de Pascua. Investigaciones Marinas 27, 19-23.

Palma S. and Apablaza P. (2004) Abundancia estacional y distribució $\mathrm{n}$ vertical del zooplancton gelatinoso carn ivoro en una á rea de surgencia en el norte del sistema de la Corriente de Humboldt. Investigaciones Marinas 32, 49-70.

Palma S., Apablaza P. and Soto D. (2007) Diversity and aggregation areas of planktonic cnidarians of the southern channels of Chile (Boca del Guafo to Pulluche Channel). Investigaciones Marinas 35, 71-82.

Palma S. and Rosales S. (1995) Composición, distribució n y abundancia estacional del macroplancton de la bah'ía de Valpara'iso. Investigaciones Marinas 23, 49-66.

Palma S. and Silva N. (2004) Distribution of siphonophores, chaetognaths, euphausiids and oceanographic conditions in the fjords and channels of southern Chile. DeepSea Research Part II: Topical Studies in Oceanography 51, 513-535.

Pavez M.A., Landaeta M.F., Castro L.R. and Schneider W. (2010) Distribution of carnivorous gelatinous zooplankton in the upwelling zone off central Chile (austral spring 2001). Journal of Plankton Research 32, 1051-1065.

Pierrot-Bults A.C. and Angel M.V. (2013) Pelagic biodiversity and biogeography of the Oceans. Biology International 51, 9-35.

Pugh P.R. (1974) The vertical distribution of the siphonophores collected during the Sond Cruise, 1965. Journal of the Marine Biological Association of the United Kingdom 54, 25-90.

Pugh P.R. (1984) The diel migrations and distributions within a mesopelagic community in the North East Atlantic. 7. Siphonophores. Progress in Oceanography 13, 461-489.

Pugh P.R. (1999) Siphonophorae. In Boltovskoy D. (ed.) South Atlantic zooplankton. Leiden: Backhuys Publishers, pp. 467-513. 